\title{
Solid waste management in the paper industry
}

\author{
Isabella Devichi Wibowo ${ }^{1 *}, P$. Purwanto ${ }^{1,2}$, and $S$. Suherman ${ }^{1,2}$ \\ ${ }^{1}$ Master Program of Environmental Science, Post-Graduate Studies, Universitas Diponegoro, \\ Semarang - Indonesia \\ ${ }^{2}$ Department of Chemical Engineering, Faculty of Engineering, Universitas Diponegoro, Semarang \\ - Indonesia
}

\begin{abstract}
The industry developed rapidly since the Industrial Revolution in the 18th century. The side effect of industrial development was a large amount of non-hazardous waste and hazardous waste. All of this waste must be managed properly so that environmental sustainability is maintained and does not cause harm or problems to the community. A review will be conducted from various research journals in various countries and the types of waste also vary, namely plastic, pulp and paper industry waste, and other solid waste. A comparison of solid waste management will be carried on to reduce the generation of waste in the environment.
\end{abstract}

Keywords: Industry, solid waste, management

\section{Introduction}

The paper industry has many sectors, namely paper for printing and packaging. Even though now it is in the digital era where the use of paper for printing documents is very minimal, different things happen for the paper used for packaging. Packaging of paper material is currently still very much needed and desirable, especially in the type of corrugated box, which is currently through an online shop system that becomes a trend nowadays. This trend brings the result that packaging on delivery in the form of corrugated boxes is very widely used, especially the use of plastic is criticized in various parts of the world because it damages the aquatic ecosystem.

Just like other industries, the paper industry also naturally produces waste. There are two types of waste produced, namely solid waste and liquid waste. In the case study conducted at PT X, located in Kudus Regency, Indonesia, the waste management carried out has followed the applicable regulations. But, its utilization has not been carried out optimally, especially in this paper, which will focus on solid waste. Solid wastes produced include Waste Water Treatment Plant (WWTP) sludge and domestic wastes such as plastic, wire, and wood originating from the raw material for paper production itself, which are

\footnotetext{
* Corresponding author: devichipinchi@gmail.com
} 
waste paper. The WWTP sludge recycled into a chip/chipboard and resold, while domestic waste is disposed of in the landfill. Therefore, it will be sought for solid waste management from several journals in various countries to be input for optimal waste management in the industry to make better waste management for PT X.

\section{Solid waste management}

\subsection{Pulp and paper waste treatment}

Waste paper in paper mills will always be reused because it benefits the environment and the economy. For the environment, waste paper is not just thrown away and pollutes the environment. For the economy, waste paper can reduce costs incurred for raw materials, because the waste paper is reused in the paper machine as raw material. Based on the study results, the use of pulp as raw materials greatly contributes the impact to the environment and provides global warming potential (GWP), acidification potential (AP), and eutrophication potential (EP) in papermaking. Therefore, scenarios with recovered fiber as raw material are considered suitable alternatives for implementation in the process, when it compared to scenarios that use virgin fiber. This is indicated by the environmental impact assessment of those two scenarios considered by expressing positive values that emphasize negative impacts on the environment. The difference between the environmental impacts of the proposed scenario lies in the complexity of the manufacturing process, the demand for resources and additives, the energy demand for the manufacturing process, and the transportation of materials to the factory. However, paper production using the used raw materials is adjusted according to the needed specifications, because it is different from the raw materials using virgin pulp $[1,2,3,4]$.

Waste management must pay attention to the potential of the management and development of raw materials for the growing paper industry. Waste paper that is used as a raw material in PT $\mathrm{X}$ has various types, so it is important to sort out the chemicals contained in each type of paper such as fillers, retention aids, adhesives, coatings, biocides, and synthetic binders. The chemical contained also affects the ability of the paper to be recycled. Raw materials that contain many chemicals are more difficult to be recycled in paper machines because the paper is indeed produced with additives according to their purpose to add strength to the paper. Not only chemicals, but fiber types in the waste paper also affect their ability to be recycled. Therefore, it requires an analysis of the characteristics of the types of fiber in the waste paper before used as raw materials in the paper mill $[5,6,7,8,9]$.

Paper sludge can also be processed and reused as raw material for paper production by biological and chemical processing. The development of the system is by anaerobic digestion (AD), the idea of pulp and paper mill waste (P\&P) to reduce the burden of pollution and biogas production, as a renewable energy source. Research on pulp and paper mill sludge has shown that chemical pre-treatment (e.g., Alkali) is an acceptable and costeffective way to increase $\mathrm{AD}$ from primary and secondary sludge when compared with other methods studied [10].

Besides recycling as raw material for paper production, another option for waste paper management is to change waste paper into other products, namely bio ethanol and bio plastics (poly-3-hydroxybutyrate), and secondary fuel production. These products have a better impact on the environment $[11,12,13]$. 
One type of waste paper used as raw material for making paper is cardboard. The remaining used cardboard that not included in the paper machine is stacked and left alone because it will affect the quality of paper products if mixed with other raw materials. Therefore, there is a solution to utilize this cardboard waste for electricity generation. The efficient use of waste cartons can be realized through pyrolysis to obtain carbon and solid $\operatorname{tar}[14]$.

\subsection{Plastic wastes}

Another waste generated from the paper production process is plastic waste. Plastic waste originates from the plastic content of the most widely used waste paper raw material at PT $\mathrm{X}$. The raw materials that have the most plastic containing are supermix and carton box. Supermix is a mixture of various types of paper with many plastic contaminants. Due to previous use, the carton box contains plastic tape or duct tape which is still attached, causing it to become a plastic contaminant. The amount of plastic waste produced at PT X is not just a little. It can be about 3 tons of plastic waste per day discharged to the landfill. Landfill should be the last option in processing industrial waste. Preferably, before land filling, plastic waste can be used first. PT X has been trying to use plastic waste turned into pellets for reprocessing into kerosene or diesel fuel. However, the utilization has not been successful because the characteristics of different types of plastic affect the melting point so that it cannot use simultaneously $[15,16,17]$.

\subsection{Printing wastes}

Paper raw materials originating from the printing industry such as duplex carton and art paper types have the potential to have high chemical content. The chemicals contained in paper from the printing industry are inks and solvents, which contain heavy metals in them. If the raw material containing these chemicals is used for food-grade paper raw materials, the chemical content can move to that food. Therefore, in the production process at PT X, this type of raw material is not used for paper production with food-grade certification, but paper production for packaging paper [18, 19, 20].

\section{Waste management of paper industry in Indonesia}

\subsection{Current status}

It could be said that the management of waste management in the paper industry is done quite well. The paper industry has realized the importance of preserving the environment by managing waste by implementing an ISO 14001 waste management system (SML). Also, several industries have implemented a Company Performance Rating Assessment Program in Environmental Management (PROPER) initiated by the Ministry of Environment of the Republic of Indonesia. With the implementation of the system, it is expected that the industry, especially the paper industry in Indonesia, it is better at managing waste from the inside first before finally being discharged into the environment, of course, with environmental standards that have been applied. One of the waste management that has been implemented is by processing rejects or pulp from paper machines that are processed 
at WWTP and produce solid waste and liquid waste. Especially at PT X, there is a step before the reject is processed at WWTP, which processes the reject in dissolved air flotation (DAF). DAF is the process for the paper slurry to split the sludge and the water that can be used in paper machines again.

\subsection{Improvement}

As industrial technology continues to develop, waste management in the paper industry in Indonesia is also developing. There is a study to conduct an industry-based sustainable economic circular approach 4.0. Research is based on case studies of waste management in several regions in Indonesia, namely Jakarta, Magelang, Semarang, and Yogyakarta. From these studies, it is known that the management of waste management in the city has experienced various improvements. In Semarang, namely in the Jatibarang Landfill as the centre of the Semarang City waste disposal area, the waste is processed into methane gas and distributed to the community as cooking gas. The waste flow starts from collecting garbage at the community level, then sent to the TPS using community vehicles, and finally sent to the landfill by environmental agent trucks. In Magelang, waste treatment technology is applied by composting, leachate treatment, and landfill gas collection. It's just that the application is hindered by the limitations of technology, human resources, and financial support to provide appropriate processing technology. In Yogyakarta, waste is generated from urban areas, hospitals, hotels, and tourism. There is also a cow farm in the waste area, which is dangerous to health if consumed. Waste continues to accumulate in the Yogyakarta landfill, and no treatment has been carried out by the local government. In another case in Jakarta, the waste treatment here has been carried out well. The landfill area has been made with a simple water treatment installation (IPAS) technology, composting, and an integrated treatment site in Bantar Gebang.

The application of industry-based smart waste management is expected to be able to make the management of equitable distribution in Indonesia better and integrated using Information and Communication Technology (ICT).

In a study in Pati Regency, precisely in the Sukoharjo landfill, and from the results of the study obtained the calculation that in 2022 this landfill will be full. Therefore, in the area, the Reduce, Reuse, Recycle (3R) process was carried out through the process of composting and recycling inorganic waste to reduce the waste generation in the landfill. Of course, it can work as expected if there is good cooperation from various walks of life to implement this system in all Pati District areas.

The progress of good waste management must be accompanied by high commitment at all levels of society and government on an ongoing basis, as well as being regularly evaluated so that expectations can be achieved for a healthier environment for sustainable development $[21,22]$

\section{Conclusions}

Waste management in PT X has been carried out well with the implementation of ISO 14001 environmental management systems and PROPER that is audited annually (surveillance).

However, there are still several wastes whose management has not yet been maximized, even though it has the potential to be utilized. The many alternatives waste management can be input and choice to develop waste management in PT X. Of course, the method to be chosen is adjusted to the conditions at PT X itself. 
The thing to note is to observe the characteristics of the waste generated at PT X so that the processing is carried out by these characteristics. The potential that can be done is by processing plastic waste into a product that can be used for other purposes and developing treatment in WWTP with composting technology. There are still many development ideas about processing that can be applied, not limited to this article.

\section{References}

1. W. M. Cheung, V. Pachisia, Facilitating waste paper recycling and repurposing via cost modelling of machine failure, labour availability and waste quantity, Resources, Conservation and Recycling, Volume 101, August 2015, Pages 34-41, Newcastle upon Tyne, UK (2015)

2. M. Sun, Y. Wangb L. Shia, J. J. Klemeš, Uncovering energy use, carbon emissions and environmental burdens of pulp and paper industry: A systematic review and metaanalysis, Renewable and Sustainable Energy Reviews, Volume 92, September 2018, Pages 823-833, China (2018)

3. C. Ghinea, M. Petraru1, I. M. Simion, D Sobariu, H. T. A Bressers, M. Gavrilescu, Life cycle assessment of waste management and recycled paper systems, Environmental Engineering and Management Journal, August 2014, Vol.13, No. 8, 2073-2085, Romania (2014)

4. S. Bousios, E. Worrell, Towards a Multiple Input-Multiple Output paper mill: Opportunities for alternative raw materials and sidestream valorisation in the paper and board industry, Resources, Conservation and Recycling, Volume 125, October 2017, Pages 218-232, The Netherlands (2017)

5. E. Sevigne-Itoiz, C. M. Gasol, J. Rieradevall, X. Gabarrell, Methodology of supporting decision-making of waste management with material flow analysis (MFA) and consequential life cycle assessment (CLCA): case study of waste paper recycling, Journal of Cleaner Production, Volume 105, 15 October 2015, Pages 253-262, Spain (2015)

6. S. van Ewijk, J. Y. Park, M. R. Chertow, Quantifying the system-wide recovery potential of waste in the global paper life cycle, Resources, Conservation and Recycling, Volume 134, July 2018, Pages 48-60 (2018)

7. B. Geueke, K. Groh, J. Muncke, Food packaging in the circular economy: Overview of chemical safety aspects for commonly used materials, Journal of Cleaner Production, Volume 193, 20 August 2018, Pages 491-505, Zurich, Switzerland (2018)

8. K. Pivnenko, M.E. Olsson, R. Götze, E. Eriksson, T.F. Astrup, Quantification of chemical contaminants in the paper and board fractions of municipal solid waste, Waste Management, Volume 51, May 2016, Pages 43-54, Lyngby, Denmark (2016)

9. S. Liang, T. Zhang, Y. Xu, Comparisons of four categories of waste recycling in

China's paper industry based on physical input-output life-cycle assessment model, Waste Management, Volume 32, Issue 3, March 2012, Pages 603-612, Beijing, China (2012)

10. M. Kamali, T. Gameiro, M. E. V. Costa, I. Capela, Anaerobic digestion of pulp and paper mill wastes - An overview of the developments and improvement opportunities, 
Chemical Engineering Journal Volume 298, 15 August 2016, Pages 162-182, Aveiro, Portugal (2016)

11. H. Al-Battashi, N. Annamalai, S. Al-Kindi, A. S. Nair, S. Al-Bahry, J. P. Verma, N. Sivakumar, Production of bioplastic (poly-3-hydroxybutyrate) using waste paper as a feedstock: Optimization of enzymatic hydrolysis and fermentation employing Burkholderia sacchari, Journal of Cleaner Production, Volume 214, 20 March 2019, Pages 236-247 (2019)

12. J. A. Rivera, V. P. López, R. R. Casado, J. S. Hervás, Thermal degradation of paper industry wastes from a recovered paper mill using TGA. Characterization and gasification test, Waste Management, Volume 47, Part B, January 2016, Pages 225235, Spain (2016)

13. L. Wang, R. Templer, R. J. Murphy, A Life Cycle Assessment (LCA) comparison of three management options for waste papers: Bioethanol production, recycling and incineration with energy recovery, Bioresource Technology Volume 120, Pages 89-98, September 2012, London, UK (2012)

14. C. Wang, Z. Lü, J. Li, Z. Cao, B. Wei, H. Li, M. Shang, C. Su, Efficient use of waste carton for power generation, tar and fertilizer through direct carbon solid oxide fuel cell, Renewable Energy, Volume 158, October 2020, Pages 410-420, PR China (2020)

15. P. M. Coelho, B. Corona, R. ten Kloosterb, E. Worrella, Sustainability of reusable packaging-Current situation and trends, Resources, Conservation \& Recycling: X, Volume 6, May 2020, 100037, Netherlands (2020)

16. V. Rossi, N. Cleeve-Edwards, L. Lundquist, U. Schenker, C. Dubois, S. Humbert, O. Jolliet, Life cycle assessment of end-of-life options for two biodegradable packaging materials: sound application of the European waste hierarchy, Journal of Cleaner Production, Volume 86, 1 January 2015, Pages 132-145, Lausanne, Switzerland (2015)

17. A. Nahman, Extended producer responsibility for packaging waste in South Africa: Current approaches and lessons learned, Resources, Conservation and Recycling, Volume 54, Issue 3, January 2010, Pages 155-162, Stellenbosch, South Africa (2010)

18. L. C. Andrade, C. G. Míguez, M. C. T. Gómez, P. M. B. Bugallo, Management strategy for hazardous waste from atomised SME: application to the printing industry, Journal of Cleaner Production, Volume 35, November 2012, Pages 214-229, Santiago de Compostela, Spain (2012)

19. K. Jelena, M. Branislav, A. Dragan, M. Aleksandra, G. Selena, O. Ivana, K. Jelena, Register of hazardous materials in printing industry as a tool for sustainable development management, Renewable and Sustainable Energy Resources, Volume 16, Issue 1, January 2012, Pages 660-667, Novi Sad, Serbia (2012)

20. K. Pivnenko, E. Eriksson, T. F. Astrup, Waste paper for recycling: Overview and identification of potentially critical substances, Waste Management, Volume 45, November 2015, Pages 134-142, Lyngby, Denmark (2015)

21. Y. A. Fatimah, K. Govindan, , R. Murniningsih, A. Setiawan, Industry 4.0 based sustainable circular economy approach for smart waste management system to achieve sustainable development goals: A case study of Indonesia, Journal of Cleaner Production, Volume 269, October 2020, Indonesia (2020) 
22. M. Viantikasari, P. Purwanto, M. A. Budihardjo, The Study of Solid Waste Management to Extend the Lifetime of Sukoharjo Landfill, Pati Regency, E3S W eb of Conferences 125, ICENIS 2019, Indonesia (2019) 